\title{
The Usefulness of Intraoperative Mobile Computed Tomography in Severe Head Trauma
}

\author{
Şiddetli Kafa Travmasunda Intraoperatif Mobil Bilgisayarlı \\ Tomografinin Faydası
}

\author{
Graziano TADDEI ${ }^{1}$, Alessandro RICCI ${ }^{1}$, Francesco DI COLA ${ }^{1}$, Giuliano MASELLI ${ }^{1}$, Sara MARZI ${ }^{1}$, \\ Renato J. GALZIO ${ }^{1,2}$ \\ ${ }^{1}$ S. Salvatore Hospital, Department of Neurosurgery, L'Aquila, Italy \\ ${ }^{2}$ University of L'Aquila, Health Sciences, L'Aquila, Italy
}

Corresponding Author: Graziano TADDEI / E-mail: merut82@gmail.com

\begin{abstract}
With modern technology, intraoperative computed tomography scans are being used in neurosurgical operative rooms. A case of severe head trauma is reported to underline how intraoperative computed tomography can improve the treatment of traumatic lesions, without changing the operative setup, with safety for patients and surgeons. The ability to perform an intraoperative computed tomography scan rapidly, at any surgical step, and with no need of any change in the operative room set or of moving the patient from the operative table improves safety both for the patient and surgeon. Intraoperative computed tomography is a very helpful tool during surgery for complex cases when a rapid evaluation of surgical manoeuvres is required.
\end{abstract}

KEYWORDS: Intraoperative computed tomography, Head trauma, Hematoma, Mobile computed tomography, Ceretom

Öz

Modern teknolojide intraoperatif bilgisayarlı tomografi taramaları nöroşirürji ameliyathanelerinde kullanılmaktadır. İntraoperatif bilgisayarlı tomografinin hastalar ve cerrahlar için ameliyathane kurulumunu değiştirmeden travmatik lezyonların tedavisini güvenli bir şekilde nasıl geliştirebileceğinin ana hatlarını vermek üzere örnek olabilecek bir ciddi kafa travması vakası bildirilmektedir. Cerrahi sırasında çok az süre içinde ve cerrahi kurulumda herhangi bir modifikasyon yapmadan istendiği zaman intraoperatif bilgisayarlı tomografi yapabilmek cerrahi protokol ve iş akışında bir değişiklik gerektirmeden hasta ve cerrahın güvenliğini arttıırı. İntraoperatif bilgisayarlı tomografi cerrahi sırasında cerrahi manevraların hızla değerlendirilmesi gerektiğinde karmaşık vakalar için çok faydalı bir araçtır.

ANAHTAR SÖZCÜKLER: İntraoperatif bilgisayarlı tomografi, Kafa travması, Hematom, Mobil bilgisayarlı tomografi, Ceretom

\section{INTRODUCTION}

Intraoperative computed tomography (iCT) is not widely used in the neurosurgery operative room (OR). However, current iCT systems are small, light, and can be easily carried in and out of the OR. Moreover, there is no need of special equipment due to the low radiation dose emitted. Some author have reported $\mathrm{ICT}$ helpfulness in the $\mathrm{OR}$, intensive care unit (ICU) and Emergency Room (ER) $(1,3,4,6)$.

The aim of this case report is to emphasize the role of iCT during surgery for severe head trauma.

\section{CASE REPORT}

A 52-year-old man was presented at the ER as the victim of a car accident. He was in comatose state with a Glasgow Coma Score of $5(E 1, V 1, M 3)$ and anisocoric pupils. The patient was sedated and intubated and underwent our diagnostic protocol for trauma. The abdominal study did not show any disorders and the whole spine evaluation did not detect fractures. The head conventional Computed Tomography is shown in Figure 1. The patient was transferred to the $O R$ to undergo surgical evacuation of the right subdural hematoma and wide decompressive craniotomy. During this procedure an unexpected important brain swelling was noted so an iCT was performed demonstrating the presence of both contralateral subdural and epidural hematomas (Figure $2 A, B$ ). Therefore, a further surgical procedure was needed and the final iCT control is shown in Figure 3. After the two surgical procedures, the patient recovered at the ICU with isocoric pupils.

\section{DISCUSSION}

In case of severe head trauma, a shorter time for diagnosis and treatment is the best way to improve outcome. Carrying out an iCT exam in OR allows obtaining faster diagnostic images which allow an increase of treatment quality and safety. Moving a ventilated and sedated patient from the OR to the CT room prolongs the time spent to diagnose a probable complication, increasing the risks of secondary brain injuries (4). 
In our Institute we use the mobile iCT CereTom (Neurologica, Danvers, MA, USA) (Figure 4). This is a modern mobile multislice scanner tool for head and neck (7). It includes a mobile CT scan with a movable workstation. Its manoeuvrability is assured with a weight of $362 \mathrm{~kg}$, dimensions of $153 \times 134 \times 72$ $\mathrm{cm}$ and a gantry diameter of $32 \mathrm{~cm}$ (7). It can therefore be

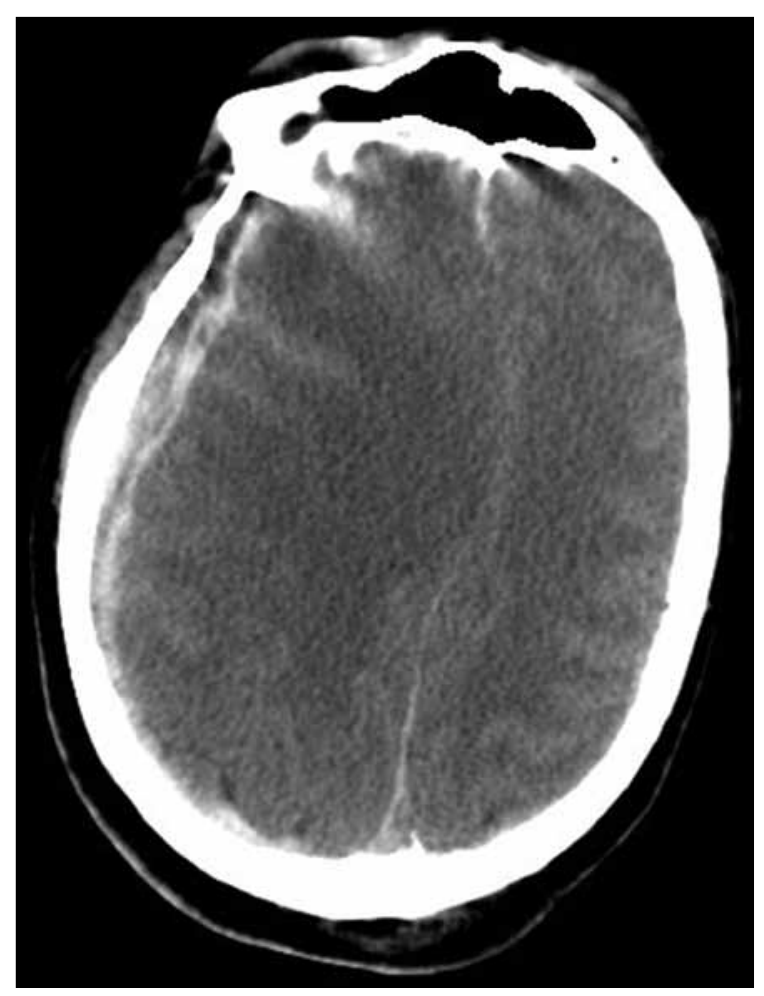

Figure 1: First pre-operative $\mathrm{CT}$ showing the traumatic acute sub-dural haematoma with severe shift of the midline. moved by only one person to rapidly reach the operating room, intensive care unit or the emergency room. It is clear that this tool can be easily integrated in every operative room without special modifications at the location (7).

The ability to perform iCT scan rapidly, at any surgical step, and with no need of any change in the operative room set or moving the patient from the operative table improves safety both for patient and surgeon (10).

As reported by Stiver, decompressive craniectomy for severe traumatic brain injuries can be followed by a new haemorrhagic lesion also outside the surgical field (8). This causes high risk related to the reduction in intracranial pressure after decompressive surgery. It should be suspected when brain swelling or cerebral herniation appears during surgery for trauma.

The case reported above demonstrates how it was possible to obtain a ready diagnosis of this acute complication directly in the OR with $\mathrm{iCT}$ and to start a new necessary surgical procedure in little time without any risk for the patient. In fact, it is known that only a rapid diagnosis and evacuation of a new subdural, epidural or intracerebral hematoma can improve outcome before the brainstem function is impaired (9).

After our preliminary experience, we suggest performing ICT in all cases of acute brain trauma needing surgical decompression or hematoma evacuation to rule out postoperative complications such as diffuse brain edema, newly occurring haemorrhages or hematomas, acute hydrocephalus etc. Rapid radiological evaluation of any pathological condition can be done directly in the OR this way, permitting prompt action and avoiding severe consequences.

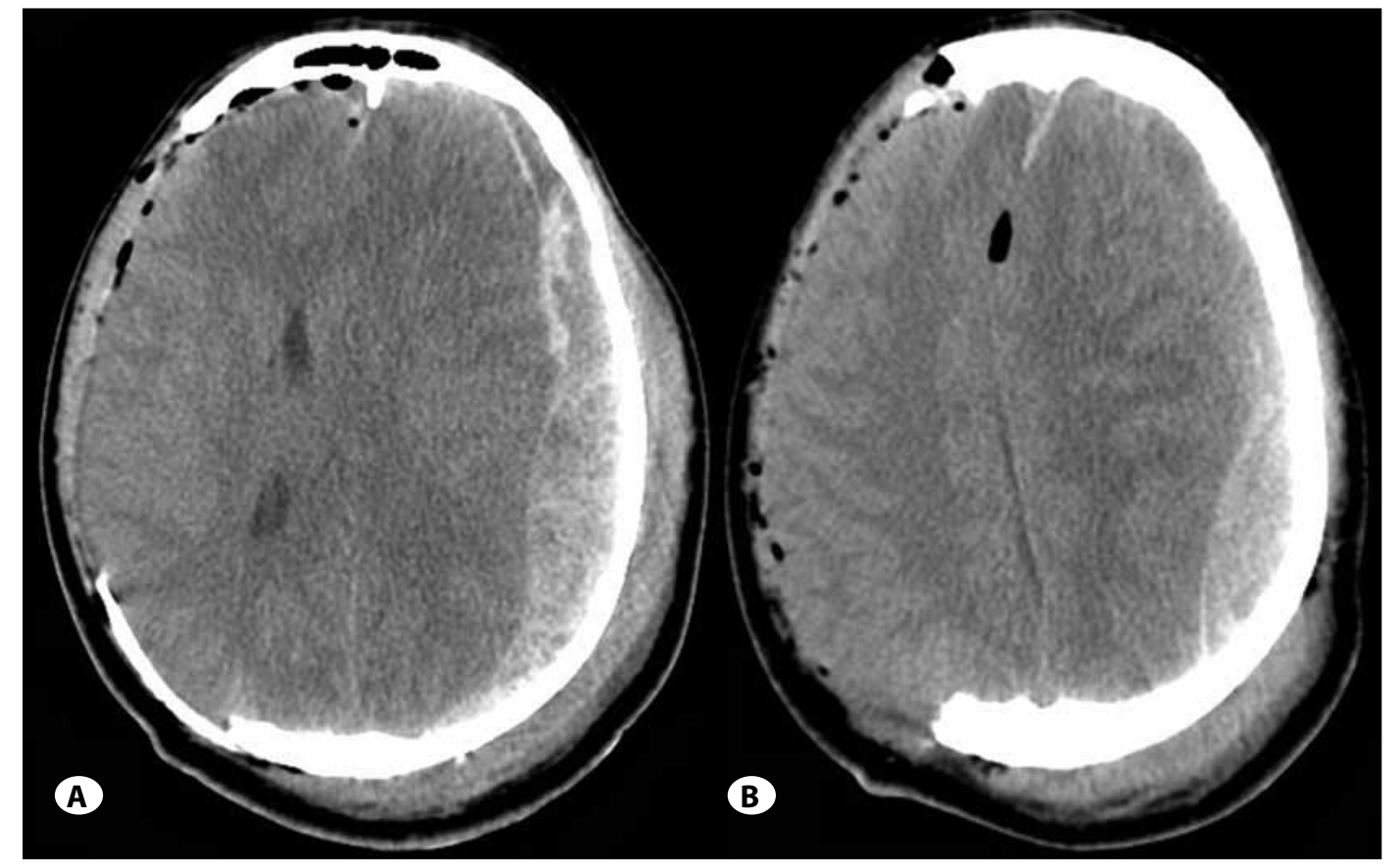

Figure 2: First post-operative iCT showing the large right decompressive craniotomy with the presence of new contralateral haematomas, sub-dural (A) and epi-dural (B). 


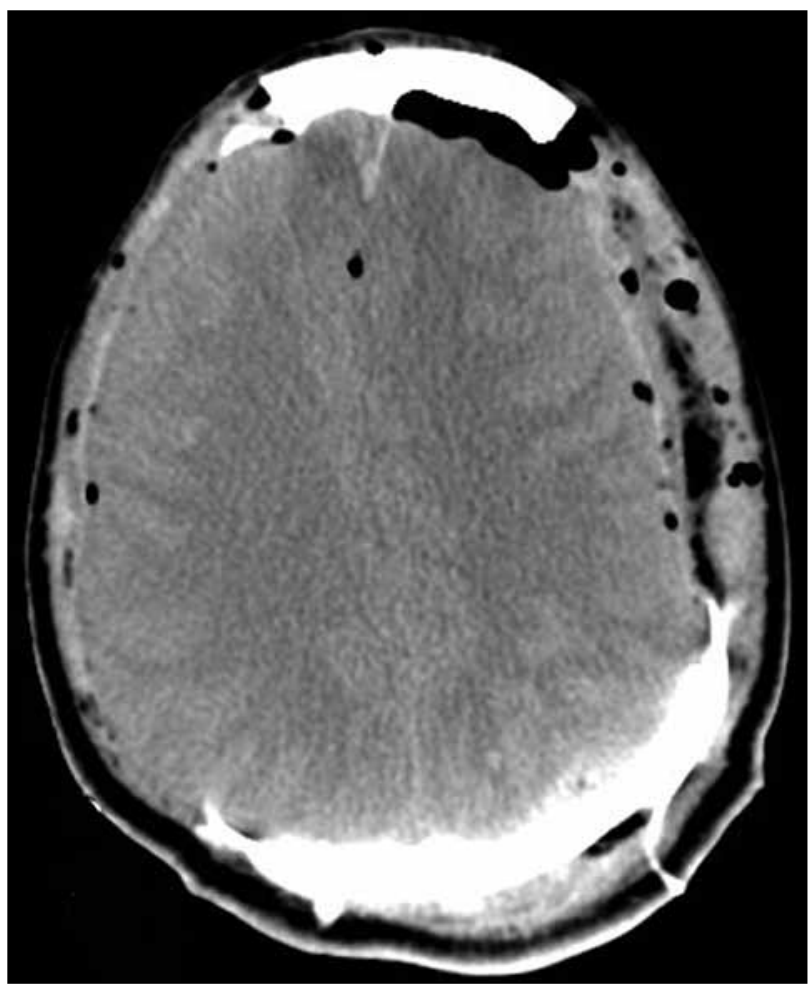

Figure 3: Last post-operative iCT: Bilateral decompressive craniotomy and no shift of medial line.

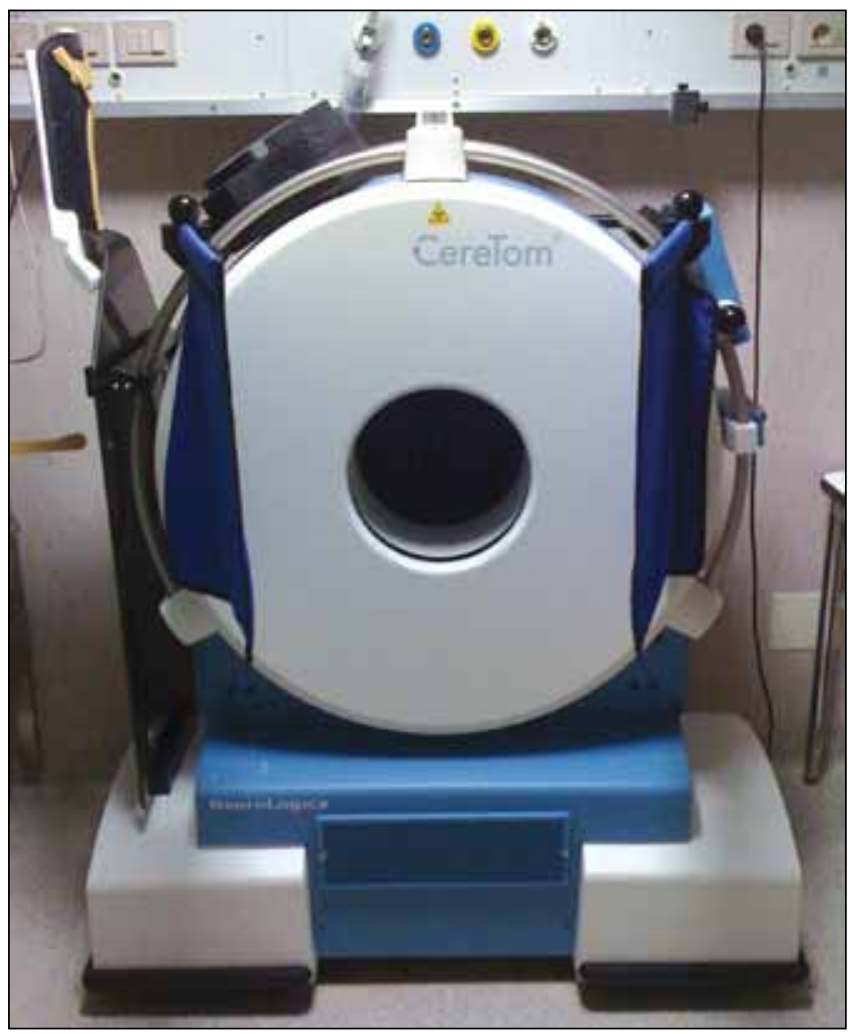

Figure 4: The iCT CereTom.

\section{CONCLUSION}

In our opinion, iCT is a very helpful tool during surgery for complex cases when a rapid evaluation of surgical manoeuvres is required. Even though former revisions have established that the use of a mobile iCT tool in the OR, ER or ICU is practical without cost increase $(2,5,7,10)$, more longterm studies about clinical effectiveness, costs analysis and diagnostic aids are required to encourage the more common use of iCT systems in everyday surgery practice.

\section{REFERENCES}

1. Butler WE, Piaggio CM, Constantinou C, Niklason L, Gonzalez RG, Cosgrove GR, Zervas NT: A mobile computed tomographic scanner with intraoperative and intensive care unit applications. Neurosurgery 42:1304-1310, 1998

2. Gunnarsson $T$, Theodorsson $A$, Karlsson $P$, Fridriksson $S$, Boström S, Persliden J, Johansson I, Hillman J: Mobile computerized tomography scanning in the neurosurgery intensive care unit: Increase in patient safety and reduction of staff workload. J Neurosurg 93:432-436, 2000

3. Hoelzle F, Klein M, Schwerdtner O, Lueth T, Albrecht J, Hosten $\mathrm{N}$, Felix R, Bier J: Intraoperative computed tomography with the mobile CT Tomoscan $M$ during surgical treatment of orbital fractures. Int J Oral Maxillofac Surg 30:26-31, 2001

4. Jin Wook K, Sang Hyung L, Young-Je S, Hee-Jin Y, Young Seob C, Hee-Won J: Mobile computed tomography: Early experience in Korea. J Korean Neurosurg Soc 48:31-36, 2010

5. Masaryk T, Kolonick R, Painter T, Weinreb DB: The economic and clinical benefits of portable head/neck CT imaging in the intensive care unit. Radiol Manage 30:50-54, 2008

6. Mirvis SE: Use of portable CT in the R Adams Cowley Shock Trauma Center. Experiences in the admitting area, ICU, and operating room. Surg Clin North Am 79:1317-1330, 1999

7. Rumboldt Z, Huda W, All JW: Review of portable CT with assessment of a dedicated head CT scanner. AJNR Am J Neuroradiol 30:1630-1636, 2009

8. Stiver SI: Complications of decompressive craniectomy for traumatic brain injury. Neurosurg Focus 26 (6):E7, 2009

9. Su TM, Lee $\mathrm{TH}$, Chen WF, Lee TC, Cheng $\mathrm{CH}$ : Contralateral acute epidural hematoma after decompressive surgery of acute subdural hematoma: Clinical features and outcome. J Trauma 65:1298-1302, 2008

10. Uhl E, Zausinger S, Morhard D, Heigl T, Scheder B, Rachinger W, Schichor C, Tonn JC: Intraoperative computed tomography with integrated navigation system in a multidisciplinary operating suite. Neurosurgery 64:231-239, 2009 